\title{
The Relationship between OCBI and Family Motivation through Self-Efficacy and Welfare in Makassar City Banking Offices
}

\author{
Andi Rahmawati \\ STIE Tri Dharma Nusantara (Makassar), Indonesia \\ *Corresponding Author: emma_rachmat@yahoo.com
}

\begin{abstract}
Employees often show a distinctive personality through their preference for family needs over jobs. Therefore, this study explores the relationship between family motivation and OCBI mediated by self-efficacy and well-being in the workplace. This research model varies from previous studies and provides the novelty of the study. As a research unit, this study uses a sample of bank employees in Makassar City with at least five years' experience as respondents. They are considered capable of delivering reliable data about the research issue (purposive sampling) using the WarpPLS 7.0 analysis tool. Interestingly, this study's new concept has revealed no evidence of an interaction between family motivation and OCBI. In this research model, all the relationships between variables were positive and significant. A recent finding of the relationship between selfefficacy and well-being in the workplace has been found and may lead to an understanding of the association between family motivation and OCBI. Empirical evidence of self-efficacy and well-being is a recent discovery that theoretically contributes to the relationship between family motivation and OCBI. In theory, this study also contributes to the existing pro-social motivation theory, explaining the impact of family motivation on OCBI in banking.
\end{abstract}

Keywords : Family motivation; Self-efficacy; Welfare; OCBI JEL Classification : G20, G21

\section{INTRODUCTION}

According to human resources psychology experts, the family has a vital role in each character. Since one of the qualities of human capital is a competent and productive character, it is arguable that character is a pioneer in creating actual job performance that is useful for families and organizations. People often work under the purpose of family motivation, not because of themselves or organization. They make family needs a priority because they consider family as the vital and dominant source of life (Poon et al., 2019). There is a strong willingness to support families, which drive people to work at a bank, 
which is sometimes interpreted as family motivation. The research question, therefore, is, "Does the family come first to the job? Tariq \& Ding (2018) suggests individual works for family motivation. Family motivation is claimed to raise awareness and trust in people to work for an added value (self-efficiency). It may inspire people to play a different role outside of their key responsibilities, henceforth known as Organizational Citizenship Behavior of Individuals (OCBI). Therefore, it is essential to conduct a study on this topic.

Bank employees frequently work extra hours and help colleagues with the sole purpose of family motivation (Umrani et al., 2019). The research hypothesis by Ju (2020), Kataria et al. (2019), Tariq and Ding (2018) suggested that family motivation could influence OCBI. Also, empirical evidence suggests that family motivation is linked to selfefficacy. For example, Bosch et al. (2018); Umrani et al. (2019) reported that stronger family motivation would increase self-efficacy. Good self-efficacy will improve OCBI. The research findings of Jawahar \& Liu (2016); Lyu et al. (2016) demonstrate that greater selfefficacy would increase OCBI.

Not only is OCBI determined by family motivation and self-efficacy and workplace wellbeing among bank employees. Therefore to deliver both literary contribution and novelty, this research investigates the relationship between self-efficacy and OCBI with the mediation of wellbeing in the workplace. Besides, workplace welfare is a portrait of the bank that commits to providing welfare for employees as a sign of gratitude and recognition of their actual performance. The latest evidence from Singh et al. (2019) suggests that the higher self-efficacy, the greater the welfare in the workplace. Employees exhibit helpful behaviour when their banks fulfil welfare for employees (Ocampo et al., 2018). It means that the bank is committed to providing welfare for increasing OCBI. Jurgita et al. (2015) show that the higher the company's commitment to employees' welfare, the greater the OCBI.

This research model is structured based on reality to obtain accurate information (Sumail \& Hasbiyadi, 2020). This research's analytical unit is bank employees in Makassar City with a minimum service of 5 years of experiences. These bank employees are assumed to have the family motivation, good self-efficacy, occupational welfare and OCBI. This paper includes hypotheses development in Section 2; methodology, data and analysis in section 3; results in Section 4; discussion in section 5; conclusion, limits and suggestions in section 6 .

\section{HYPOTHESES DEVELOPMENT}

Family motivation and OCBI: Family motivation tends to work based on the motives of family caring, family need, and family benefit. The motive for family caring is to empathize with family life based on kindness, affection, compassion and responsibility. Caring for the family is not short-term. It is ongoing so that commitment can be accomplished and performance can be improved. Calabrò et al. (2020) suggest that family motivation will enhance performance. An employee is inspired to work for the interests of the family. This life without a family feels pointless because the sun in life is the family. Tariq \& Ding (2018) state that a powerful driver to work is family. The motivation of employees to work is based on the benefit principle. His presence at work will bring real benefits, whether financial or psychological benefits, to family life. Marescaux et al. (2020) clarified that an individual's motivation to work is to support his family and himself. 
Family motivation will promote the role of OCBI. Meanwhile, OCBI is an extra behaviour outside of the primary duty. Ocampo et al. (2018) provide explanations for OCBI characteristics. For example, someone displays a function as a means of motivation from within the person to carry out a task better or exceed a set norm (Individual initiative), another trait of OCBI is the volunteer actions of employees to support staff or avoid problems with their employment (helping behaviour). Loyalty behaviour of employees towards the company is by projecting a positive image about the company, protecting the company from external threats, and promoting and attaining organizational objectives (Organizational loyalty). Therefore motivation can promote OCBI.

Research hypothesis from Ju (2020), Kataria et al. (2019), Tariq \& Ding (2018) reported that family motivation could increase OCBI. In the prosocial motivation theory framework, prosocial activity is a voluntary action that is meant to support and benefit another person or group of individuals. This view differs from that of (Umrani et al., 2019), which notes that family motivation is not significantly positive for OCBI. Alternatively, stated OCBI does not always increase the motivation of the family. Therefore, the analysis hypothesis is stated as follow:

$\mathrm{H}_{1}$. Family motivation is positively related to OCBI

Family motivation and self-efficacy: Family motivation likely affects self-efficacy. Marescaux et al. (2020) stated that family motivation strengthened with emotional bonds can increase self-efficacy to attain organizational goals. Self-efficacy thus refers to an individual's awareness and belief that affects circumstances brings meaning \& values in life. Since consciousness and faith is an ideology of an employee whose status is the motivation axis of performance development and an emotional connection in life. Family motivation is eudaimonic since it involves the responsibility to satisfy others' needs and not to be affective towards oneself. Eudaimonic is thus a pursuit of happiness that is not restricted to subjective emotions but goes deeper to establish family life's emotional aspects. The ability to enhance family life requires a high degree of self-efficacy. Research by Bosch et al. (2018); Umrani et al. (2019) have confirmed that higher family motivation contributes to greater self-efficacy. Family motivation increases self-efficacy manifested through actual work performance, wisdom, belief and meaning of life. Therefore the formulation of the hypothesis as follows:

$\mathrm{H}_{2}$. Family Motivation is positively related to Self-Efficacy

Self-efficacy and OCBI: Employees' awareness and belief to succeed generates additional important values and represent good self-efficacy. Employees with the strength of awareness and belief will show a higher efficiency of performance. Instead, employees with low awareness and belief would generate low-quality outcomes. From a psychological perspective, awareness and belief improve OCBI. The greater the understanding and the stronger the belief, the higher the OCBI. Pradhan et al. (2020) have stated that personality has considerable explanatory power to increase OCBI. The level of self-efficacy is reflected through employee proactivity. Jawahar \& Liu (2016) research shows that proactive individuals play an essential role in increasing OCBI at work. Then, Jawahar \& Liu (2016); Lyu et al. (2016) stated that the greater self-efficacy, the greater the OCBI. Therefore the formulation of the hypothesis as follows:

$\mathrm{H}_{3}$. Self-efficacy is positively related to OCBI. 
Employees with a higher level of family motivation often demonstrate greater selfefficacy. Anyone with strong awareness and belief can adequately perform their job, which subsequently added value for themselves, colleagues and the organization. As a result, OCBI is higher. Ultimately, referring to the theory of prosocial motivation that family motivation enhances self-efficacy. It supports employees' family members and assists colleagues at work without expecting external rewards, such as OCBI. Family motivation is assumed to have a direct impact on self-efficacy, whereas self-efficacy has a direct effect on OCBI. Thus, by increasing self-efficacy, family motivation has an effect on OCBI. The role of OCBI will be meaningful if accompanied by good and high-quality selfefficacy behaviors. Pradhan et al. (2020) reported that personality has a major and strong impact in increasing OCBI, it should not be argued that the quality of self-efficacy is embodied in employees' proactive personality. Jawahar \& Liu (2016) stated that proactive people play a more significant role in work performance for OCBI. Jawahar \& Liu (2016); Lyu et al. (2016) also reported that greater self-efficacy increases OCBI's role. Therefore the formulation of the hypothesis as follows:

$\mathrm{H}_{4}$. Work motivation is positively related to OCBI through self-efficacy

Self-efficacy and workplace well-being: Self-efficacy is the individuals' perception of themselves when performing a job using talents and behaviour. Some psychology experts define self-efficacy as individuals' judgments about their own ability to organize and behave to attain a particular goal performance. The greater the selfefficacy, the greater the awareness and belief in job performance. The potential of workers to perform job increases the expectation of prosperity at the workplace. Besides, workplace welfare is perceived organizational support. Joo \& Lee (2017) suggested that perceived organizational support and psychological capital on job satisfaction would influence workplace welfare. Also, Sharma \& Kumra (2020) notes that workplace welfare can be encouraged by employers and leaders' attention or concern. Therefore, self-efficacy has an influence on welfare in the workplace. Singh et al. (2019) claimed that the greater the workplace's welfare, the greater self-efficacy. Thus the hypothesis formulation is as follows:

$\mathrm{H}_{5}$. Self-efficacy is positively correlated with welfare at workplace

Welfare at the workplace and OCBI: A well-designed system of human resource management helps to enhance employers' job welfare ( $\mathrm{Li} \& \mathrm{Lin}, 2020)$, including workplace wellbeing. Workplace prosperity leads workers to have self-confidence, high self-esteem and emotional resilience (Zhang \& Shi, 2017). Employees with signs of wellbeing at work will be heavily involved in the job and will play a part in supporting colleagues. Joo \& Lee (2017) concluded that workers would be more active in work, happy with their jobs, and feel greater welfare in life when they had organizational support and higher psychological capital. This situation caused no interpersonal deviance, and there was an improvement in employee welfare and an increase in OCBI. Markova (2018) claimed that the decline in the welfare of employees was due to interpersonal deviance. Also, Duan et al. (2019) reported that assisting colleagues' behaviour was a proactive and reactive portrait that often occurs when the job was considered vital to oneself, apart from the organization. The research by Jain (2015) showed that personal volunteerism was a strong predictor of OCBI's organizational commitment. OCBI was an example of individual commitment to supporting colleagues. 
Ocampo et al. (2018) indicated that interactional justice could contribute positively to a sense of belonging among workers and often supported their colleagues. In comparison, OCBI would be reduced by companies that have low commitment. Jurgita et al. (2015) claimed that the greater the company's commitment to employees' wellbeing, the more significant the role of OCBI. Thus, the higher the welfare in the workplace, the greater the OCBI. Thus the research hypothesis is as follows

$\mathrm{H}_{6}$. Workplace welfare is positively related to OCBI.

Self-efficacy can be identified as individual behaviour with the strength to encounter adversity and to achieve satisfaction. Employees' feelings of satisfaction are reflected through the feeling of pleasure and joy at work. When workers are satisfied, they are happy and fulfilled at work. Thus OCBI increases. Gyekye \& Haybatollahi (2015) reported that OCBI's position was increased by job satisfaction. Self-efficacy can also encourage well-being in the workplace and increase OCBI at the same time. Thus the research hypothesis is as follows:

H7. Self-efficacy is positively related to OCBI mediated by well-being in the workplace.

\section{METHOD, DATA, AND ANALYSIS}

\section{Method}

The study respondents were bank employees at all commercial banks in Makassar City with a minimum service span of 5 years experience, with an expectation of delivering accurate data. The data was collected through a questionnaire instrument designed using a Likert scale ranging from strongly disagree to strongly agree. The questionnaire was tested with a validity value $(\mathrm{r}>0.30)$ and a reliability value $(>$ alpha 0.60) (Solimun et al., 2017) to generate very accurate data. 145 questionnaires were distributed, 118 questionnaires were returned, and 10 were considered faulty so that 108 surveys qualified to be tabulated. The data analysis was then performed using the WarpPLS 7.0 software, and the data analysis results were then interpreted.

\section{Data and Analysis}

Employees serving at commercial banks in Makassar City were dominated by 65\% of male employees and $35 \%$ of female employees. The banking sector currently demands professionalism, honesty, freedom of speech to exchange strategic ideas and thoughts. Therefore this attitude is more prevalent among male employees. Male workers need short and frequent rest periods in comparison with female workers. In general, psychologically, female workers do not like being led by female managers. The average employees' production age was 55\% from 20 to 35 years and $45 \%$ from 36 to 55 years. Meanwhile, the education level of employees was dominated by bachelors at $87 \%$ and then by masters at $1.3 \%$ (see Table 1 ).

Table 1. Characteristics of Respondents

\begin{tabular}{lll}
\hline Characteristics & Employees & \\
\hline Gender & Male & $65 \%$ \\
& Females & $35 \%$ \\
Age & $20-35$ years & $55 \%$ \\
& 36 - 55 years & $45 \%$ \\
Education & S1 & $87 \%$ \\
& S2 & $1,3 \%$ \\
\hline
\end{tabular}

Source: Research Finding, 2020 
Table 2. Combined Loadings and Cross Loadings

\begin{tabular}{cccccc}
\hline Indicator & $\begin{array}{c}\text { Family } \\
\text { motivation }\end{array}$ & Self-efficacy & $\begin{array}{c}\text { Workplace } \\
\text { well-being }\end{array}$ & $\begin{array}{c}\text { OCB } \\
\text { Individual }\end{array}$ & P value \\
\hline X1.1 & 0.724 & -0.360 & 0.144 & 0.231 & $<0.001$ \\
X1.2 & 0.697 & 0.027 & -0.344 & -0.116 & $<0.001$ \\
X1.3 & 0.824 & 0.105 & -0.134 & 0.029 & $<0.001$ \\
Y1.1 & -0.165 & 0.827 & 0.008 & -0.046 & $<0.001$ \\
Y1.2 & -0.097 & 0.888 & 0.029 & 0.194 & $<0.001$ \\
Y1.3 & 0.255 & 0.740 & -0.088 & 0.023 & $<0.001$ \\
Y2.1 & 0.016 & -0.127 & 0.598 & 0.337 & $<0.001$ \\
Y2.2 & -0.043 & -0.179 & 0.808 & -0.197 & $<0.001$ \\
Y2.3 & 0.024 & 0.090 & 0.805 & 0.156 & $<0.001$ \\
Y3.1 & 0.055 & 0.035 & -0.120 & 0.893 & $<0.001$ \\
Y3.2 & 0.183 & -0.224 & -0.088 & 0.766 & $<0.001$ \\
Y3.3 & -0.240 & 0.055 & 0.284 & 0.666 & $<0.001$ \\
\hline
\end{tabular}

The results of the cross-check revealed that all indicators were valid (see Table 2 and Table 3) because the load factor was $>0.30$ or $\mathrm{p}<0.001$, and the reliability of Cronbach's alpha was greater than 0.70, which implied a reliable test (Solimun et al., 2017).

Table 3. Composite reliability and Crobach's alpha

\begin{tabular}{lcccc}
\hline \multicolumn{1}{c}{ Reliability } & $\begin{array}{c}\text { Family } \\
\text { motivation } \\
(\mathbf{X 1})\end{array}$ & $\begin{array}{c}\text { Self-efficacy } \\
(\mathbf{Y 1})\end{array}$ & $\begin{array}{c}\text { Workplace } \\
\text { well-being } \\
\text { (Y2) }\end{array}$ & $\begin{array}{c}\text { OCB } \\
\text { Individual } \\
(\mathbf{Y} 3)\end{array}$ \\
\hline Composite reliability coefficients & 0.861 & 0.907 & 0.867 & 0.897 \\
Cronbach's alpha coefficients & 0.784 & 0.861 & 0.791 & 0.842 \\
\hline
\end{tabular}

Three indicators measure the model fit: The Average path coefficient (APC), Average R-squared (ARS), and Average adjusted R-squared (AARS). If the p-value is $P$ $<0.001$, the model is considered fit (Sumail \& Abdullah, 2019).

Table 4. Model Fit and Quality Indices

\begin{tabular}{clccc}
\hline No. & Model Fit and quality indices & Fit criteria & Analysis result & Description \\
\hline 1 & Average path coefficient (APC) & $\mathrm{p}<0,05$ & $0.450,(\mathrm{p}<0.001)$ & Fit \\
2 & Average R-squared (ARS) & $\mathrm{p}<0,05$ & $0.510,(\mathrm{p}<0.001)$ & Fit \\
3 & Average adjusted R-squared (AARS) & $\mathrm{p}<0,05$ & $0.503,(\mathrm{p}<0.001)$ & Fit \\
\hline Note: the level of significance of the $\mathrm{p}$ value is $\alpha 0.05$ & & &
\end{tabular}

In Table 4 , the value of the APC is 0.450 . It implies that approximately $50 \%$ is the average path coefficient. The explanatory (independent) variable can be claimed to be related to the dependent variable. Value for ARS $=0.510 .0$. It indicates that the average correlation of determinants is above $50 \%$, so there is a correlation between variables. Then AARS value is 0.503 . These values show that the correlation of several independent variables exceeds $50 \%$. The three indicators are $\mathrm{p}<0.001$ so that the model is fit since it is higher than $50 \%$. Thus, the model can explain the data so that interpretations and hypothesis testing can be carried out. 


\section{RESULTS}

The estimated loading coefficient value indicates each indicator's weight as a measure of each latent variable. The mean value represents each indicator's actual state based on the respondents' assessment or perception.

Table 5 . The value of factor weights and the mean value of family motivation variables

\begin{tabular}{clcc}
\hline \multicolumn{1}{c}{ Variables } & \multicolumn{1}{c}{ Indicators } & Factor Loadings & $\begin{array}{c}\text { Mean } \\
\text { Indicators }\end{array}$ \\
\hline \multirow{3}{*}{ Family motivation (X1) } & Be kind to family members (X1.1) & 0.724 & 3.8 \\
& Beneficial for family (X1.2) & 0.697 & 2.4 \\
& Caring for Family (X1.3) & $\mathbf{0 . 8 2 4}$ & $\mathbf{4 . 0}$ \\
\hline
\end{tabular}

Note: the bold numbers represented the most significant indicator

The primary determinant of family motivation to work is caring for the family at 0.824. Bank employees confirm that they are motivated to take care of their families. The lowest indicator is beneficial for the family at 0.697 , with a mean value of 2.4 or below.

Table 6. Factor weight values and mean of self-efficacy variables

\begin{tabular}{clcc}
\hline Variables & Indicators & Factor Loadings & Mean Indicators \\
\hline \multirow{3}{*}{ Self-efficacy (Y1) } & Awareness (Y1.1) & 0.827 & 3.8 \\
& Self-confidence (Y1.2) & $\mathbf{0 . 8 8 8}$ & 3.9 \\
& Value-added (Y1.3) & 0.740 & 2.5 \\
\hline
\end{tabular}

Note: the bold numbers represented the most significant indicator

The highest weight indicator that represents the self-efficiency of bank employees is self-confidence, which is 0.888 . The employees explained that they perceived an ability to perform the job well. The lowest indicator is the added value of 0.740 with a mean value of 2.5 or less.

Table 7. The value of factor weights and the Mean values of welfare in the workplace

\begin{tabular}{clcc}
\hline \multicolumn{1}{c}{ Variables } & \multicolumn{1}{c}{ Indicators } & $\begin{array}{c}\text { Factor } \\
\text { Loadings }\end{array}$ & $\begin{array}{c}\text { Mean } \\
\text { Indicators }\end{array}$ \\
\hline \multirow{3}{*}{ Workplace welfare (Y2) } & Employer's duty of care (Y2.1) & 0.598 & 2.5 \\
& Workplace Rewards and Recognition & $\mathbf{0 . 8 0 8}$ & $\mathbf{4 . 0}$ \\
& (Y2.2) & 0.805 & 3.8 \\
\hline
\end{tabular}

Note: the bold numbers represented the most significant indicator

The most significant measure in workplace welfare is Rewards and Recognition. It implies that employees believe that their supervisor supports their subordinates at 0.808 , and the employees respond to this by 4.0 on average, which means good. Meanwhile, As the lowest predictor, the employer's duty of care is 0.598 . The mean value of 2.5 indicates employee perception toward supervisor care that does not meet expectation or even below expectation.

Table 8. Factor weight values and mean values of OCB individual

\begin{tabular}{clcc}
\hline Variables & \multicolumn{1}{c}{ Indicators } & Factor Loadings & Mean Indicators \\
\hline \multirow{3}{*}{ OCB individual (Y3) } & Individual initiative (Y3.1) & $\mathbf{0 . 8 9 3}$ & 3.9 \\
& Helping behavior (Y3.2) & 0.766 & 3.8 \\
& Organizational loyalty (Y3.3) & 0.666 & 2.4 \\
\hline
\end{tabular}

Note: the bold numbers represented the most significant indicator 
The most significant indicators representing the OCBI are individual initiatives. It means individual self-motivation to perform tasks better or surpass the predetermined expectations is 0.8933 . The mean value of employees who respond to this is 3.9 , which means good. Meanwhile, organizational loyalty is a low indicator with a value of 0.666. The average value of 2.4 indicates employee loyalty. It demonstrates an inability to show a positive image of the company, protect it against external challenges, and promote organizational objectives.

Table 9. Results of path coefficient analysis 1

\begin{tabular}{|c|c|c|c|c|}
\hline \multicolumn{2}{|c|}{ The relationship between variables } & \multirow{2}{*}{ Direct Effect } & \multirow{2}{*}{ p-value } & \multirow{2}{*}{ Description } \\
\hline Explanatory variables & Response variables & & & \\
\hline Family motivation (X1) & OCBI (Y3) & 0.058 & 0.273 & $\begin{array}{c}\text { Not } \\
\text { significant }\end{array}$ \\
\hline Family motivation (X1) & Self-efficacy (Y1) & $0.735^{* * *}$ & $<0.001$ & $\begin{array}{l}\text { highly } \\
\text { significant }\end{array}$ \\
\hline Self-efficacy (Y1) & OCBI (Y3) & $0.413^{* * *}$ & $<0.001$ & $\begin{array}{l}\text { highly } \\
\text { significant }\end{array}$ \\
\hline Self-efficacy (Y1) & Workplace welfare (Y2) & $0.619^{* * *}$ & $<0.001$ & $\begin{array}{l}\text { highly } \\
\text { significant }\end{array}$ \\
\hline Workplace welfare (Y2) & OCBI (Y3) & $0.427^{\star * *}$ & $<0.001$ & $\begin{array}{l}\text { highly } \\
\text { significant }\end{array}$ \\
\hline
\end{tabular}

Tabel 10. Result of path coefficient analysis 2

\begin{tabular}{|c|c|c|c|c|c|}
\hline $\begin{array}{l}\text { Explanatory } \\
\text { variables }\end{array}$ & $\begin{array}{l}\text { Mediating } \\
\text { variables }\end{array}$ & $\begin{array}{l}\text { Response } \\
\text { variables }\end{array}$ & Indirect Effect & p-value & Description \\
\hline $\begin{array}{l}\text { Family } \\
\text { motivation }(X 1\end{array}$ & $\begin{array}{l}\text { Self-efficacy } \\
\text { (Y1) }\end{array}$ & OCBI (Y3) & $0.264^{* * *}$ & $<0.001$ & $\begin{array}{l}\text { complete } \\
\text { mediation }\end{array}$ \\
\hline $\begin{array}{l}\text { Self-efficacy } \\
\text { (Y1) }\end{array}$ & $\begin{array}{l}\text { Workplace } \\
\text { welfare (Y2) }\end{array}$ & OCBI (Y3) & $0.455^{\star * *}$ & $<0.001$ & $\begin{array}{l}\text { full } \\
\text { mediation }\end{array}$ \\
\hline
\end{tabular}

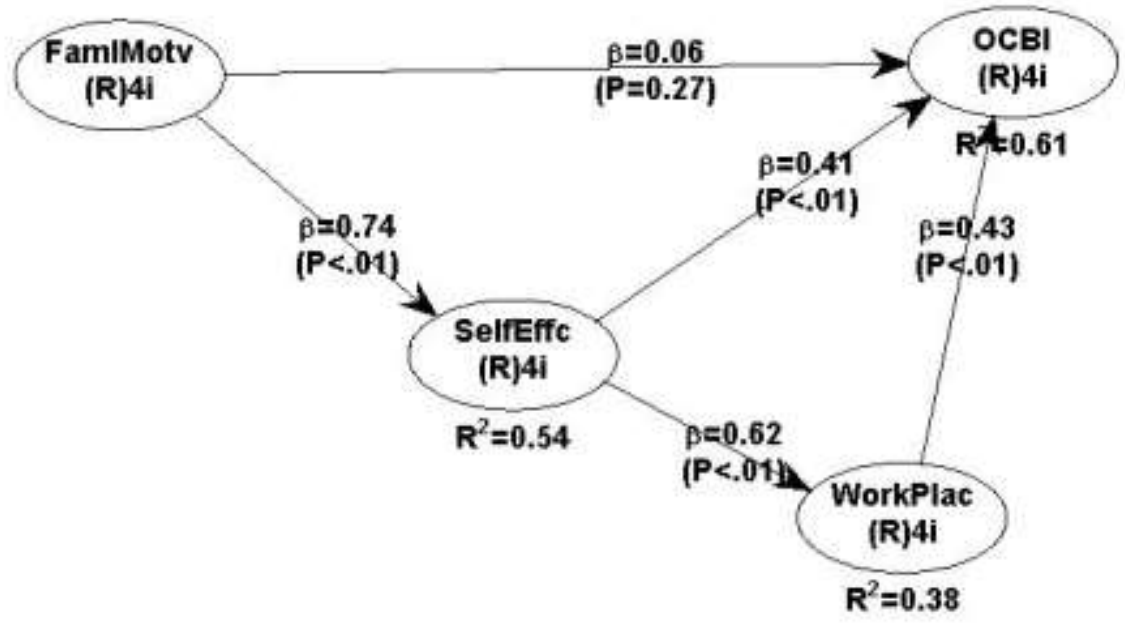

Figure 1. The relationship between variables

The relationship between variables is shown in Table 9 and Figure 1. First, direct relationship: family motivation is positively related to OCBI but not significant $(\beta=0.058$, $p>0.273$ ). Since the $p$-value is higher than 0.05 , so empirical evidence is not obtained. 
Family motivation positively and significantly affects self-efficacy, with empirical evidence $(\beta=0.735, \mathrm{p}<0.001)$. Self-efficacy has a positive and significant effect on OCBI with empirical evidence $(\beta=0.413, p<0.001)$. Self-efficacy has a positive and significant effect on workplace welfare with empirical evidence of $(\beta=0.619, \mathrm{p}<0.001)$. Then workplace welfare has a positive and significant effect on individual OCB with empirical evidence $(\beta=0.427, \mathrm{p}<0.001)$. Second, the indirect relationship: Family motivation positively and significantly impacts self-efficacy-mediated by OCBI $(\beta=0.264, p<0.001)$ with full mediation as empirical evidence. In addition, the positive and significant impact of self-efficacy on OCBI is mediated by workplace welfare $(\beta=0.455, p<0.001)$ with full mediation as empirical support.

\section{DISCUSSION}

This study rejects the hypothesis that the higher the family motivation, the higher the OCBI. It indicates that no evidence has been found of a positive and significant influence of family motivation on OCBI. In other words, family motivation has no particular effect on OCBI. The research hypothesis is confirmed by this analysis (Umrani et al., 2019). This research hypothesis, however, is not in line with research from Ju (2020), Kataria et al. (2019), Tariq \& Ding (2018), which states that family motivation can increase OCBI. Several indications suggest this inconsistency. For example, high family motivation will improve employee interest in the job to earn financial incentives for fulfilling family needs. The role of the OCBI, meanwhile, is voluntary conduct without financial incentives. Furthermore, there can be a high degree of family motivation for workers who have great concern and passion for work. Employees appear to exhibit extreme behaviour. It occurs because family motive that induces immoral conduct causes workers to avoid supporting their families (Kataria et al., 2019) so that they are less involved in helping workplace colleagues. The outcomes of this research are not supported by prosocial motivation theory. Based on prosocial motivation theory, Prosocial behaviour is a voluntary action that benefits people and families.

This study showed that the greater the family motivation, the greater the selfefficacy. Because family motivation reflects an emotional commitment to family members (Marescaux et al., 2020), it may improve self-efficacy to achieve organizational objectives. Self-efficacy is the ability of a person to produce genuine works with awareness, belief and meaning $\mathrm{n}$ life. This study supports Bosch et al. (2018); Umrani et al. (2019). Family motivation increases self-efficacy, which manifests through actual work, which has a value of consciousness, belief, and meaning in life. It is consistent with a prosocial motivation theory.

The better self-efficacy, the higher the role of OCBI was also revealed in this research. Bank employees who have self-awareness and self-confidence at work often seem to be helping employees in the workplace. Thus, in the role of helping colleagues, OCBI is a portrait of the personality of employees. The role of OCBI will be significant if good self-efficacy behaviour accompanies it. Sharma \& Kumra (2020) indicated that personality is an essential determinant of OCBI improvement. Employees demonstrate a higher OCBI with a high degree of adaptability. Therefore, self-efficacy can improve OCBI, especially for males. Meanwhile, women showed OCBI regardless of their level of self-confidence. It is indisputable that the level of self-efficacy is reflected in the proactive personality of employees. Jawahar \& Liu (2016) indicated that proactive people would 
significantly impact OCBI on awareness at the workplace. This study confirms the hypothesis suggested by Jawahar \& Liu (2016); Lyu et al. (2016) that the higher the selfefficacy level, the higher the OCBI.

This study's findings are exciting, and new concepts have not clarified that family motivation does not significantly impact OCBI because family motivation is not a determining factor of OCBI for employees. However, Employees perceive that the higher the family motivation, the greater the self-efficacy and the greater the OCBI. It is, therefore, appropriate to consider self-efficacy a complete mediation variable.

Self-efficacy can lead to workplace well-being. Employees with awareness, confidence, actual performance and added value work demonstrate good self-efficacy. Authentic work experience of workers increases the expectation of a better working climate because the fact that the organization offers stimulus such as compensation for work success makes workers happier. This happiness is very significant and a feature of job satisfaction. Staff have a sense of well-being at work. Furthermore, welfare at work is perceived as organizational support. Joo \& Lee (2017) stated that perceived organizational support and psychological capital on happiness create prosperity. Although welfare still appears to be low, superiors have been trying to pay attention to subordinates' welfare at work. Sharma \& Kumra (2020) argues that employers' or leaders' interests may promote welfare at work. This study, therefore, supports Singh et al. (2019)'s hypothesis that the better self-efficacy, the greater the welfare at work.

The wellbeing experienced by employees at work will encourage motivation to support colleagues. Psychologically, both constructive and reactive attitudes towards supporting colleagues are stronger when workers are satisfied at work. Duan et al. (2019) stated that helping colleagues' behavior is a proactive and reactive image that only emerges when the job is worthwhile for employees, apart from organization. Empirical evidence shows that bank employees more frequently demonstrate the role of better performing their duties or exceeding established standards. This behavior is attributed to the perception of employees that the organization is committed to establish welfare in the workplace. A research by Jain, (2015) describes the positive predictor of organizational contribution to OCBI by personal volunteerism. It was also found that the voluntary behavior of bank employees was to help colleagues or solve work problems. This is because employees who have positive interactional justice and have sense of belongings also support colleagues. Ocampo et al. (2018) suggest that interactional justice positively determines employees' sense of belonging and mutual assistance. In addition to these two indicators, employee loyalty to the company, such as showing a good company image, protecting the company against external threats and supporting the bank's organizational objectives. The organization gives loyal workers benefits under the belief that it is committed to offering welfare to its employees. Instead, low-commitment organizations would lower OCBI. Jurgita et al. (2015) stated that the more significant the organization's contribution to employee welfare, the greater the OCBI. This research thus supports the hypothesis that the greater the wellbeing at work, the higher the OCBI.

This study supports the hypothesis that the greater the self-efficacy, the better the well-being at work, the higher the OCBI in the banking sector. It is also a discovery not found in prior studies. Self-efficiency contributes immensely to opportunities for welfare in the workplace. Self-efficacy means that the bank employees feel satisfied at work based 
on their awareness and belief. Employees express feelings of satisfaction through a satisfied, joyful and cheerful attitude when working. They would be happier at work if employees get job satisfaction, so the OCBI increases. Gyekye \& Haybatollahi (2015) reported that work satisfaction would increase OCBI. The welfare in the workplace is, therefore, called the full mediation variable.

\section{CONCLUSION, LIMITATIONS, AND SUGGESTIONS}

\section{Conclusion}

In general, there is a positive and significant relationship between variables in this research model. However, the relationship between family motivation and OCBI cannot provide concrete evidence. It can be claimed as a novelty of the findings. Despite such limitations, the thesis has succeeded in answering all research questions and successfully achieving research objectives. Furthermore, this research also investigated the main factors influencing OCBI by making self-efficacy and well-being in the workplace significant mediators. Indeed, self-efficacy and well-being in the workplace are recent developments and may help understand the relationship between family motivation and OCBI. This research evaluates empirical evidence and theoretical concepts on self-efficacy and well-being in the workplace, used as significant mediators between exogenous and endogenous variables. This research's theoretical framework also contributes to the field of prosocial motivation theory by exploring the effects of family motivation on OCBI. Moreover, this study's results have many significant practical effects for bank managers who are concerned with understanding the psychological mechanisms underlying family motivation and its influence on OCBI.

\section{Limitations}

This thesis is still restricted to confirm the prosocial motivation theory's intervariables, although other motivation theories, including motivation theory $X$ and theory Y, Two Factor Theory and Vroom's Expectancy Theory, can be contrasted to prosocial motivation theory. The findings of this analysis would be more profound if paired with other theories. Moreover, the evaluation of OCBI is based entirely on employees' perceptions and is thus subjective, therefore has limited generalizability.

\section{Suggestions}

This report's focus is on banking employees, and no comparative comparison is yet available between the bank and other sectors, such as the manufacturing industry, for further knowledge purposes. Based on Figure 1 above, $61 \%$ of the OCBI total variance, $54 \%$ of the overall self-efficacy variance, and $38 \%$ of the total welfare variance were clarified in the research model. The remaining 39\% for OCBI variance, $46 \%$ for variance in self-efficacy and $62 \%$ for the variance in the well-being at work could be considered in future studies. The new findings in this research indicate that family motivation has a positive but not significant effect on OCBI. It contradicts previous studies, so it is essential to examine why this unusual effect occurs in future research.

\section{REFERENCE}

Bosch, M. J., Heras, M. Las, Russo, M., Rofcanin, Y., \& Grau i Grau, M. (2018). How context matters: The relationship between family supportive supervisor behaviours 
and motivation to work moderated by gender inequality. Journal of Business Research, 82(August 2017), 46-55.

Calabrò, A., Torchia, M., Jimenez, D. G., \& Kraus, S. (2020). The role of human capital on family firm innovativeness: the strategic leadership role of family board members. International Entrepreneurship and Management Journal, 4(2), 126-140.

Duan, J., Wong, M., \& Yue, Y. (2019). Organizational helping behavior and its relationship with employee workplace well-being. Career Development International, 24(1), 18-36.

Gyekye, S. A., \& Haybatollahi, M. (2015). Organizational citizenship behavior: An empirical investigation of the impact of age and job satisfaction on Ghanaian industrial workers. International Journal of Organizational Analysis, 23(2), 285-301.

Jain, A. K. (2015). Volunteerism and organisational culture: Relationship to organizational commitment and citizenship behaviors in India. Cross Cultural Management: An International Journal, 22(1), 116-144.

Jawahar, I. M., \& Liu, Y. (2016). Proactive personality and citizenship performance The mediating role of career satisfaction and the moderating role of political skill. Career Development International, 21(4), 378-401.

Joo, B. K., \& Lee, I. (2017). Workplace happiness: work engagement, career satisfaction, and subjective well-being. Evidence-Based HRM, 5(2), 206-221.

Ju, C. (2020). Work motivation of safety professionals: A person-centred approach. Safety Science, 127(August 2019), 43(2), 212-225.

Jurgita Lazauskaite-Zabielske, Urbanaviciute, I., \& Bagdziuniene, D. (2015). The role of prosocial and intrinsic motivation in employees' citizenship behaviour. Baltic Journal of Management, 10(3), 345-36.

Kataria, A., Garg, P., \& Rastogi, R. (2019). Do high-performance HR practices augment OCBs? The role of psychological climate and work engagement. International Journal of Productivity and Performance Management, 13(3), 43-59.

Li, X., \& Lin, C. (2020). The influence of high-commitment work system on work wellbeing: the mediating role of psychological empowerment and the moderating role of leader trust. Personnel Review,8(3), 66-80.

Lyu, Y., Zhu, H., Zhong, H. J., \& Hu, L. (2016). Abusive supervision and customeroriented organizational citizenship behavior: The roles of hostile attribution bias and work engagement. International Journal of Hospitality Management, 53, 69-80.

Marescaux, E., Rofcanin, Y., Las Heras, M., Ilies, R., \& Bosch, M. J. (2020). When employees and supervisors (do not) see eye to eye on family supportive supervisor behaviours: The role of segmentation desire and work-family culture. Journal of Vocational Behavior, 121(July), 6(2), 131-146.

Markova, G. (2018). Not bad, just unhappy: diminished well-being as a motive for interpersonal deviance. Leadership and Organization Development Journal, 39(1), 66-81.

Ocampo, L., Acedillo, V., Bacunador, A. M., Balo, C. C., Lagdameo, Y. J., \& Tupa, N. S. (2018). A historical review of the development of organizational citizenship 
behavior (OCB) and its implications for the twenty-first century. Personnel Review, $47(4), 821-862$.

Poon, D. B., Watt, H. M. G., \& Stewart, S. E. (2019). Future counselors' career motivations, perceptions, and aspirations. Higher Education, Skills and Work-Based Learning, 10(1), 155-170.

Pradhan, R. K., Jena, L. K., \& Panigrahy, N. P. (2020). Do sustainability practices buffer the impact of self-efficacy on organisational citizenship behaviour?: Conceptual and statistical considerations. Journal of Indian Business Research, 4(2), 65-78.

Sharma, P. K., \& Kumra, R. (2020). Examining the mediating role of work engagement on the relationship between workplace mindfulness and organizational justice and its association with well-being. South Asian Journal of Business Studies.

Singh, S. K., Pradhan, R. K., Panigrahy, N. P., \& Jena, L. K. (2019). Self-efficacy and workplace well-being: moderating role of sustainability practices. Benchmarking, $7(2), 41-56$.

Solimun., Adji A. R., dan Nurjannah. (2017). Metode Statistika Multivariat: pemodelan Persamaan Struktural (SEM) Pendekatan WarpPLS. UB Press Malang.

Sumail, L. O., \& Abdullah, S. (2019). Innovative Behavior And Emotional Intelligence Of Managers In Managing A Catering Business. Jurnal Manajemen, 23(2), 290.

Sumail, L. O., \& Hasbiyadi. (2020). Alms-Awareness Behavior, Serotonin Hormone, and Corporate Age. Jurnal Manajemen, 24(3), 358.

Tariq, H., \& Ding, D. (2018). Why am I still doing this job? The examination of family motivation on employees' work behaviors under abusive supervision. Personnel Review, 47(2), 378-402.

Umrani, W. A., Siyal, I. A., Ahmed, U., Ali Arain, G., Sayed, H., \& Umrani, S. (2019). Does family come first? Family motivation-individual's OCB assessment via self-efficacy. Personnel Review, 49(6), 1287-1308.

Zhang, S., \& Shi, Q. (2017). The relationship between subjective well-being and workplace ostracism The moderating role of emotional intelligence. Journal of Organizational Change Management, 30(6), 978-988. 